\title{
Factors controlling marine and estuarine sublittoral macrofauna
}

\author{
D. J. WILDISH \\ Department of the Environment, Fisheries and Marine Service, Biological Station; \\ St. Andrews, N. B., Canada
}

\begin{abstract}
The state of knowledge of marine and estuarine sublittoral benthic synecology may be said to be still in a descriptive stage of study. Much of the recent literature of the subject concerns either qualitative and quantitative descriptions of communities or associations, or concepts of such associations including diversity, stability and succession. It is the purpose of this paper to present a theory, based on a hierarchy of multiple limiting physical and biotic factors, for study of the controls governing community composition, biomass and productivity. Three major biotic factors are considered as qualitative and quantitative controls: food supply, supply of colonizing larvae, and interspecies competition. They are discussed and new techniques are suggested which may help in understanding the mechanisms of control.
\end{abstract}

\section{INTRODUCTION}

Two major themes may be found in the literature of estuarine and marine sublittoral macrofauna. The first is a description of animal associations based on numbers of individuals, species numbers and biomass (see review of Gray, 1974) in relation to sediments (Fager, 1964; Kinner et al., 1974; Christie, 1975; Ward, 1975) sedimentation (Moore, 1931), salinity (Newell, 1964; Wildish, 1970; Boesch, 1972; Wolff, 1974) and biotic factors (Dayton \& Hessler, 1972; Campbell \& Meadows, 1974; Moore, 1975). Productivity measurements for marine sublittoral macrofauna have also recently been made (Peer, 1970; Burke \& Mann, 1974; Klein et al., 1975; Chambers $\&$ Milne, 1975). The second theme may be described as theoretical accounts of sublittoral macrofaunal associations in terms of community structure (see Watkins et al., 1973) or diversity (Sanders, 1968; Pianka, 1966) in terms of their successional stage (Leigh, 1965; Shugart, 1973) or stability/time relationships (Sanders, 1968). It is not the purpose here to review this work exhaustively but to present reasons for rejecting as working hypotheses, the currently popular concepts mentioned under theme two. A theoretical framework is suggested which will, I believe, direct field and laboratory experimental work towards a better empirical basis for the subject. 


\section{COMMUNITY CONCEPTS}

Peters (1976) has recently crystallized the objections of a growing number of authors (see for example Goodman, 1974; Hurlbert, 1971; Jacobs, 1974; Livingston, 1976) to the use of community concepts such as diversity, succession, and stability/ time relationships, at least as working scientific hypotheses. All three are considered to be ecological tautologies. A tautology is defined as a logical deductive argument based on premises which need not have observed empirical correspondence to real life and whose conclusions are implicit in the premises. An important property of tautology is that it cannot be empirically tested and is incapable of yielding predictions.

A second basis for rejection involves an enquiry as to whether such community concepts have been practically useful. The example used here is from the pollution biology literature. Macrobenthic fauna are recognized to be good indicators of point source pollution because they cannot move away from its source (Reish, 1973). In general, two problems are involved in work of this kind: a test to determine what spatial effect the pollutant may have had, and a temporal one to determine what pre- and post-operational effects occur at the same station.

In the last ten years considerable data on spatial testing have appeared (see for example, Crippen \& Reish, 1969; Holland et al., 1973; Hendricks et al., 1974) and on temporal testing (Pearson, 1972; Rosenberg, 1972, 1973). Analytical methods used have relied heavily on community concepts, including diversity/stability and succession. Although it has been shown that pollution induced changes do occur and can be reversed, if the pollution source is stopped, no empirical base has appeared from which predictions could be made to other locations at other times. Each field observation or experiment involves high costs, and remains site specific in its results and applications.

\section{MULTIPLE LIMITING FACTOR THEORY}

Sublittoral macrofaunal community composition, biomass and productivity are controlled by multiple interactive physical and biotic factors. Major physical factors include: salinity, temperature, current speed, oxygen availability, sediments and water/sediment exchange phenomena. Major biotic factors include food supply, the supply of colonizing larvae and interspecific competition.

The rest of this discussion will be limited to the major biotic factors involved in controlling marine and estuarine sublittoral macrofauna.

\section{FOOD LIMITATION}

A convenient way of classifiying macrobenthic associations is by their method of feeding. Thus, Pearson (1971) described five trophic groups: motile predators, algal scrapers, surface deposit feeders, deposit swallowers and suspension feeders. The first two groups are quite specialized and make up only a small proportion of the total. 
The bulk of species are either suspension or deposit feeders. In many cases, trophic relationships of given groups are inferred and experimental observations on methods of feeding have yet to be made. Of particular interest in this is the degree to which a particular species may be facultative for suspension or deposit feeding.

In the trophic group amensalism hypothesis, Rhoads \& Young (1970) suggest that there are interactions between the two trophic groups causing inhibition of one group, the suspension feeders, by re-suspended sediments which clog the filtering mechanism and by prevention of larval settlement due to the absence of a suitable substrate for filter feeding epifauna.

Rhoads \& Young (1970) recognized that the amensalism hypothesis could not explain why predominantly suspension and deposit feeding associations develop in soft sediments. To do so, I propose the trophic group mutual exclusion hypothesis. It states (1) that sublittoral macrofaunal community composition, biomass and productivity are food limited; (2) the basic exclusion mechanism is a physical factor: the current speed through its control on the supply of suspended food and its inhibitory effect on the development of the later stages of deposit-feeding associations by control of oxygen exchange between sediment and bottom water and by removing biogenically re-suspended sediments.

The food of macrobenthic animals is mainly aerobic, heterotrophic microorganisms (see Newell, 1965; Fenchel, 1969) or small meiobenthic animals such as nematodes, ciliates, etc. which depend trophically on microorganisms. In inshore areas, autotrophs may also provide a relatively small proportion of food directly to suspension feeders or to deposit feeders from a diatom sediment surface film. A major factor considered to control numbers of bacteria, and hence availability of macrobenthic food, is sediment particle surface area (Zobell, 1946). Experimental evidence for this consists either of determination of bacterial numbers by classical methods in cultures containing sediments of known particle diameter (see Zobell, 1946; Fenchel, 1970; Krumbein, 1970, 1971a) or determination of organic carbon and nitrogen in relation to sieved sediment fractions (Newell, 1965; Longbottom, 1970). All of these results suggest that with decreasing particle diameter and hence increasing particle surface area, the numbers or biomass of bacteria increase proportionately. Newell (1970) has summarized the evidence that bacteria do attach firmly to sediment surfaces and that this enables adsorption of particulate or dissolved nutrients necessary for bacterial growth. Ionic concentration of sea water is known to be important for the attachment process (Meadows, 1965). These data apply mainly to deposited sediments but similar conclusions apparently apply to detritus: bacteria associations in the water column (see Jørgensen, 1966). The experimental data to support this contention are not yet convincing (see Banse, 1974). In bottom water, carbon or other nutrients could be limiting to bacterial growth.

According to the trophic group mutual exclusion hypothesis the proportion of suspension to deposit feeding species which develop on a vacant sediment is decided primarily by the current speed spectra in the bottom water immediately above it. Sanders (1956), Pearson (1971) and Krumbein (1971b) emphasized the importance of current speed; the latter author indicates that bacterial numbers of surface sediment and bottom water depended on the direction and intensity of tidal currents. Observa- 
tional data on bottom currents, which include tidal, wave induced or reaction currents, are generally not reported with macrobenthic distribution data, so a test of this cannot be made with existing data. Nevertheless, the hypothesis could explain apparent anomalies of sediment: animal associations recognized by McNulty et al. (1962), Rhoads \& Young (1970), Levinton (1972), Pearson (1971) and in my own data from the Bay of Fundy (Wildish et al., in preparation). Most workers report that deposit feeding associations are associated with fine grained sediments less than $63 \mu \mathrm{m}$ and low current speeds and that mixed sediments contain a higher proportion of suspension feeders. Sediment distribution usually is related directly to the contemporary current speed immediately above it (see Hjulström, 1939). The effect of macrobenthos, such as algae, in preventing sediment scouring and stabilizing the sediment: water interface is emphasized in recent work (see Rhoads, 1974). Thus, in L'Etang Inlet, Canada, a suspension feeding association is associated with a sediment of median particle diameter 10 to $15 \mu \mathrm{m}$. The sediment surface is stabilized by surface microflora and the contemporary current speed is high (maximum $95 \mathrm{~cm} / \mathrm{sec}$ ) although not reaching a critical velocity to cause erosion. In a sandy sediment (median particle diameter $0.325 \mathrm{~mm}$ ) a polychaete deposit feeding association is present with a lower current speed of $35 \mathrm{~cm} / \mathrm{sec}$ maximum in which velocities sometimes caused erosion.

Diagnostic of the early stages of deposit feeding associations are low current speeds which if they occur on a fine sediment with particle diameters less than $63 \mu \mathrm{m}$ develop into an intensively reworked deposit feeding association dominated by bivalves of the kind described by Rhoads \& Young (1970). On sandy sediments with low current speeds a deposit feeding association dominated by polychaetes develops and here biogenic reworking is less evident. Biogenic reworking involves burrowing, increasing the surface water content, reducing the stability of the mudwater interface and allowing resuspension by weak currents. Coprophagy of the large number of fecal pellets may involve "seeding" of the pellets to increase colonization by microflora (Fenchel, 1970). Hylleborg (1975) describes the "gardening" activities of the lugworm, Abarenicola pacifica, which ingests sediment and utilizes attached bacteria. Fecal matter is enriched to support the growth of further bacteria as food. One functional purpose of biogenic reworking from the point of view of the deposit feeder is to increase oxygen availability and optimize the food available to them, thus resuspended sediments provide a large surface area for attachment of microflora in sea water containing nutrients and oxygen. Of course it is not of value to the deposit feeder to resuspend particles which are then swept away by tidal currents. Mills (1969) provides an example of the dynamic balance between an amphipod, Ampelisca abdita, and the sediment in which it lives. The tube-living, sediment-ingesting Ampelisca occurs in large numbers on the shore during summer, reducing the grain size of surface sediments by its trophic habits which eventually causes sediment-tidal current instability and washout of the Ampelisca tubes.

By contrast, suspension feeding associations develop in areas with higher current speeds and, at least in those developing on soft sediments, may involve some means of stabilizing the sediment-water interface. In warmer climates this stabilization may take the form of coral reefs and here symbiosis with autotrophs becomes a prominent feature increasing the suspension feeding association productivity. Hildreth \& Crisp 
(1976) show that current speed and particulate matter concentration does not affect the filtration rate of suspension feeding bivalve molluscs. Removal of suspended matter from water depends simply on the particulate matter concentration and current speed. There are inherent, probably species specific, natural limits to this relationship for both particulates and current beyond which further increases do not enhance growth or are injurious (Galtsoff, 1964; Kirby-Smith, 1972). Kirby-Smith (1972) has shown that, at low current speeds, growth of the bay scallop is reduced because of lack of food. This is in spite of the fact that phytoplankton-food removal efficiency was $63 \%$ compared with $30 \%$ removal at the higher, optimum current speeds for growth. These experimental results are consistent with field observations (see Hildreth \& Crisp, 1976) in that dense communities only develop where currents are high because of the efficient removal of microbial food by such molluscs. In temperate-water marine sponges food removal efficiency was 44 to $77 \%$ and bacteria were sufficient as food (Reiswig, 1975).

Within the last ten years a biochemical method has been adapted by Holm-Hansen \& Booth (1966) to monitor adenosine 5 'triphosphate (ATP) universally present in living organisms of sea water and sediments. ATP determination by firefly bioluminescence assay is a simple, sensitive and reproducible measure linked to living microbial biomass which may be crucial in laboratory and field experiments to test the trophic group mutual exclusion hypothesis. Major interfering effects in the firefly bioluminescence assay (Wildish, 1976) include ionic inhibition or enhancement by anions or cations in solution and light emission stimulation by non-adenylate nucleotides. Both these difficulties can be overcome by suitable modifications involving liquid chromatographic column pretreatment to remove ions (Hodson et al., 1976) and analytical methods which consider the first few seconds of light emission (Wildish, 1976). The method is considered to be additional to classical methods of determining total and viable microbial numbers and biomass. The strong point of classical methods is that they are taxon specific although often poorly reproducible.

The adsorption of a monomolecular layer of nitrogen at liquid nitrogen temperatures and use of B.E.T. equations (Brunauer et al., 1938) or by measurement of ethylene glycol vapor adsorption (Marin \& Jacobs, 1964) could be used to accurately measure sediment surface areas. Slabaugh \& Stump (1964) have shown that marine sediments measured in this way have surface areas one or two orders of magnitude greater than calculations based on their median particle diameters. The difference apparently is due to shape irregularities and micropores of the particles. The geological origin of the particle also influences the surface area: glauconites had a greater surface than quartz sediments. In freshwater-lake sediments studied by Banin et al. (1975) the 0 to $2 \mu \mathrm{m}$ clay fraction contributed 98 to $99 \%$ of the surface area.

The two methods mentioned provide considerable promise in testing the trophic group mutual exclusion hypothesis. Experimental tests possible include: (1) A definitive test with sediments of known surface area to determine microbial biomass and productivity maxima where nutrients and oxygen are not limiting. (2) Field observations of microbial ATP, current speed and suspended sediments just above the sediment surface in a typical deposit and suspension feeding association. The study should be on a seasonal and tidal basis and would require use of special sampling methods to 
take water samples a known distance above the sediment (see Smith, 1971; Joyce, 1973). (3) Laboratory experiments, particularly with deposit feeders, to determine the extent to which gut microflora contribute to the trophic requirements of the animal. Schwarz et al. (1976) have suggested that such microorganisms may play a significant role in deep sea animals. (4) To determine the role of bacterioplankton as food for suspension feeders.

\section{COLONIZING LARVAL SUPPLY AND COMPETITION}

The colonization of a vacant sediment will depend on the supply of larvae which reach it and their suitability to live in it. Factors which influence larval supply include the species composition of larval donors, nearness of the donors to the vacant site, current direction and velocity (Bousfield, 1955), and the temporal nature of the supply including the survival time of the larvae in plankton. Besides this it is known that benthic larvae may delay settling and select certain sediments (Fenchel, 1975; Moore, 1975 ) based on the bacterial content or presence of pheromones (Campbell \& Meadows, 1974).

Species competition is probably most important at the settling stage as suggested by Rhoads \& Young (1970) in the amensalism hypothesis. An inverse relationship was found between recruitment of Macoma and the abundance of Pontoporeia by Sergestråle (1973) probably because the amphipods eat the newly settled spat. Other authors such as Woodin (1974), Fenchel (1975) and Aller et al. (1974) provide empirical support for interspecific competition at the settling stage affecting species composition.

\section{DISCUSSION}

A central question of sublittoral macrofaunal synecology concerns the nature of the controls regulating community composition, biomass and productivity. Community concepts are considered as unlikely to provide hypotheses which lead to an empirically testable base for the reasons given above. Whether future hypotheses based on a hierarchy of multiple limiting factors, as suggested here, can do so still remains to be seen. In both field and laboratory experiments it should be possible to isolate the factors involved if the parameters are properly chosen or controlled.

Colonizing larval supply and interspecific competition are the major factors controlling community composition if temperature and salinity differences are removed. The major factor controlling biomass and productivity is the food supply. The potential for productivity of suspension feeders can be assessed from uptake efficiency measurements and current speed times microbial biomass content of the water. Potentials for deposit feeders should be given by the sediment microbial biomass content, inclusive of biogenically resuspended sediments, efficiency of removal of microflora and possibly the sediment oxygen which may limit macrofaunal activity as well as production of microbial food. Of considerable interest in this is the turnover rate or production of the microbes themselves which has been determined by measuring rates 
of incorporation of labelled substrates (see Carney \& Colwell, 1976; Herbland $\&$ Pages, 1976) or from oxygen uptake studies (Pamatmat \& Banse, 1969).

Although suspension feeding and deposit feeding associations are contrasted here - they may be regarded as extremes in a gradient from one type to the other. Actual macrobenthic associations consist of mixtures of each trophic type. The potential productivity of each type can be measured in the same way as suggested above and the two values summed in proportion to the percentage of each trophic type present.

\section{LITERATURE CITED}

Aller, R. C. \& Dodge, R. E., 1974. Animal-sediment relations in a tropical lagoon Discovery Bay, Jamaica. J. mar. Res. 32, 209-232.

Banin, A., Gal, M., Zohar, Y. \& Singer, A., 1975. The specific surface area of clays in lake sediments - measurement and analysis of contribution in Lake Kinnert, Israel. Limnol. Oceanogr. 20, 278-282.

Banse, K., 1974. On the role of bacterioplankton in the tropical ocean. Mar. Biol. 24, 1-5.

Boesch, D. F., 1972. Species diversity of marine macrobenthos in the Virginia area. Chesapeake Sci. 13, 206-211.

Bousfield, E. L., 1955. Ecological control of the occurrence of barnacles in the Miramichi estuary. Bull. natn. Mus. Can. 137, 1-69.

Brunauer, S., Emmett, D. H. \& Teller, E., 1938. The adsorption of gases in multimolecular layers. J. Am. chem. Soc. 60, 309-316.

Burke, M. V. \& ManN, K. H., 1974. Productivity and production: biomass ratios of bivalve and gastropod populations in an eastern Canadian estuary. J. Fish. Res. Bd Can. 31, $167-177$.

Campbell, J. I. \& Meadows, P. S., 1974. Gregarious behaviour in a benthic marine amphipod (Corophium volutator). Experentia 30, 1396-1397.

Carney, J. F. \& Colwell, R. R., 1976. Heterotrophic utilization of glucose and glutamate in an estuary: effect of season and nutrient load. Appl. environm. Microbiology 31, 227-261.

Chambers, M. R. \& Milne, H., 1975. The production of Macoma baltbica (L.) in the Ythan Estuary. Estuar. coast. mar. Sci. 3, 443-455.

Christie, N. D., 1975. Relationship between sediment texture, species richness and volume of sediment sampled by a grab. Mar. Biol. 30, 89-96.

Crippen, R. W. \& Reish, D. J., 1969. An ecological study of the polychaetous annelids associated with fouling material in Los Angeles Harbour with special reference to pollution. Bull. S. Calif. Acad. Sci. 68, 169-186.

Dayton, P. K. \& Hessler, R. R., 1972. Role of biological disturbance in maintaining diversity in the deep sea. Deep-Sea Res. 19, 199-208.

Fager, E. W., 1964. Marine sediments: effects of a tubebuilding polychaete. Science, N. Y. 143, 356-359.

Fenchel, T., 1969. The ecology of marine microbenthos. IV. The structure and functions of the benthic ecosystem, its chemical and physical factors and the microfauna communities with special reference to the ciliated Protozoa. Ophelia 6, 1-182.

- 1970. Studies on the decomposition of organic detritus derived from the turtle grass Thalassia testudinum. Limnol. Oceanogr. 15, 14-20.

- 1975. Factors determining the distribution patterns of mud snails (Hydrobiidae). Oecologia 20, 1-18.

Galtsoff, A. M., 1964. The American oyster Crassostrea virginica Gmelin. Fish. Bull. U.S. 64, 480 pp.

Goodman, D., 1974. The validity of the diversity-stability hypothesis. Proc. int. Congr. Ecol. $75,79$. 
Gray, J. S., 1974. Animal-sediment relationships. Oceanogr. mar. Biol. 12, 223-261.

Hendricks, A., Henley, D., Wyatt, J. T., Dickson, K. L. \& Silvey, J. K. G., 1974. Utilization of diversity indices in evaluating the effect of a paper mill effluent on bottom fauna. $\mathrm{Hy}$ drobiologia 44, 463-474.

Herbland, A. \& Pages, J., 1976. Note on the variability of heterotrophic activity measurements by the ${ }^{14} \mathrm{C}$ method in sea water. Mar. Biol. 35, 211-214.

Hildreth, D. I. \& Crisp, D. J., 1976. A corrected formula for calculation of filtration rate of bivalve molluses in an experimental flowing system. J. mar. biol. Ass. U.K. 56, 111-120.

Hjulström, F., 1939. Transportation of detritus by moving water. In: Recent marine sediments. Ed. by P. D. Trask. Am. Ass. Petrol. Geol. Tulsa, Oklahoma, 5-31.

Hodson, R. E., Holm-Hansen, O. \& Azam, F., 1976. Improved methodology for ATP determination in marine environments. Mar. Biol. 34, 143-149.

Holland, J. S., Maciolek, N. J. \& Oppenheimer, C. H., 1973. Galveston Bay benthic community structure as an indicator of water quality. Contrib. mar. Sci. 17, 169-188.

Holm-Hansen, O. \& Booth, C. R., 1966. The measurement of adenosine triphosphate in the ocean and its ecological significance. Limnol. Oceanogr. 11, 510-519.

Hurlbert, S. H., 1971. The nonconcept of species diversity: a critique and alternative parameters. Ecology 52, 577-586.

Hylleberg, J., 1975. Selective feeding by Abarenicola pacifica with notes on Abarenicola vagabunda and a concept of gardening in lugworms. Ophelia 14, 113-137.

Jacobs, J., 1974. Diversity, stability and maturity in ecosystems influenced by human activities. J. Proc. int. Congr. Ecol. 1, 94-95.

Jørgensen, C. B., 1966. Biology of suspension feeding. Pergamon Press, Oxford, 357 pp.

Joyce, J. R., 1973. An improved bottom-water sampler. J. mar. biol. Ass. U.K. 53, 741-744.

Kinner, P., Maurer, D. \& Leathem, W., 1974. Benthic invertebrates in Delaware Bay: Animalsediment associations of the dominant species. Int. Revue ges. Hydrobiol. 59, 685-701.

Kirby-Smith, W. W., 1972. Growth of the bay scallop: influence of experimental water currents. J. exp. mar. Biol. Ecol. 8, 7-18.

Klein, G., Rachor, E. \& Gerlach, S. A., 1975. Dynamics and productivity of two populations of the benthic tube-dwelling amphipod Ampelisca brevicornis (Costa) in Helgoland Bight. Ophelia 14, 139-160.

Krumbein, W. E., 1970. On the behaviour of pure cultures of marine microorganisms in sterilized and re-inoculated sediments. Helgoländer wiss. Meeresunters. 20, 17-28.

- 1971a. Sedimentmikrobiologische Untersuchungen I. - Uber die Abhängigkeit der Keimzahl von der Korngröße. Vie Milieu (Suppl.) 22, 253-264.

- 1971b. Sediment microbiology and grain-size distribution, as related to tidal movement, during the first mission of the West German underwater laboratory "Helgoland". Mar. Biol. 10, 101-112.

Leigh, E. G., 1965. On the relation between the productivity, biomass, diversity and stability of a community. Proc. natn Acad. Sci. U.S.A. 53, 777-783.

Levinton, J., 1972. Stability and trophic structure in deposit-feeding and suspension feeding communities. Am. Nat. 106, 472-486.

Livingston, R. J., 1976. Diurnal and seasonal fluctuations of organisms in a north Florida estuary. Estuar. coast. mar. Sci. 4, 373-400.

Longbottom, M., 1970. The distribution of Arenicola marina (L.) with particular reference to the effects of particle size and organic matter of the sediments. J. exp. mar. Biol. Ecol. 5, $138-157$.

McNulty, J. K., Work, R. C. \& More, H. B., 1962. Some relationships between the infauna of the level-bottom and the sediment in South Florida. Bull. mar. Sci. Gulf Caribb. 12, 322-332.

Meadows, P. S., 1965. Attachment of marine and freshwater bacteria to solid surfaces. Nature, Lond. 207, 1108.

Mills, E. L., 1969. The community concept in marine zoology, with comments on continua and instability in some marine communities: a review. J. Fish. Res. Bd Can. 26, 1415-1428. 
Moore, H. B., 1931. The muds of the Clyde sea area. III. Chemical and physical considerations: rate of sedimentation and fauna. J. mar. biol. Ass. U.K. 17, 325-328.

Moore, P. G., 1975. The role of habitat selection in determining the local distribution of animals in the sea. Mar. Behav. Physiol. 3, 97-100.

Marin, R. E. \& Jacobs, H. S., 1964. Surface area determination of soils by adsorption of ethylene glycol vapor. Proc. Soil Sci. Soc. Am. 28, 190-194.

Newell, R. C., 1964. Some factors controlling the upstream distribution of Hydrobia ulvae. Proc. zool. Soc., Lond. 142, 85-106.

- 1965. The role of detritus in the nutrition of two marine deposit feeders, the prosobranch Hydrobia ulvae and the bivalve Macoma baltbica. Proc. zool. Soc., Lond. 144, 25-45.

- 1970. Biology of intertidal animals. Elsevier, New York, 555 pp.

Pamatmat, M. M. \& Banse, K., 1969. Oxygen consumption by the sea bed. Limnol. Oceanogr. 14, 250-259.

Pearson, T. H., 1971. Studies on the ecology of the macrobenthic fauna of Lochs Linnhe and Eil, west coast of Scotland. II. Analysis of the macrobenthic fauna by comparison of feeding groups. Vie Milieu (Suppl.) 22, 53-91.

- 1972. The effect of industrial effluent from pulp and paper mills on the marine benthic environment. Proc. R. Soc. (B) 180, 469-485.

Peer, D. L., 1970. Relation between biomass, productivity, and loss to predators in a population of a marine benthic polychaete, Pectinaria byperborea. J. Fish. Res. Bd Can. 27, $2143-2153$.

Peters, R. H., 1976. Tautology in evolution and ecology. Am. Nat. 110, 1-12.

Pianka, E. R., 1966. Latitudinal gradients in species diversity: a review of concepts. Am. Nat. 100, 33-46.

Reish, D. J., 1973. The use of benthic animals in monitoring the marine environment. J. environm. Planning Pollut. Control (G.B.) 1, 32-38.

Reiswig, H. M., 1975. Bacteria as food for temperate-water marine sponges. Can. J. Zool. 53, 582-589.

Rhoads, D. C., 1974. Organism-sediment relations on the muddy sea floor. Oceanogr. mar. Biol. 12, 263-300.

- \& Young, D. K., 1970. The influence of deposit feeding organisms on sediment stability and community trophic structure. J. mar. Res. 28, 150-178.

Rosenberg, R., 1972. Benthic faunal recovery in a Swedish fjord following the closure of a sulphite pulp mill. Oikos 23, 92-108.

- 1973. Succession in benthic macrofauna in a Swedish fjord subsequent to the closure of a sulphite pulp mill. Oikos 24, 244-258.

Sanders, H. L., 1956. Oceanography of Long Island Sound 1952-1954. X. The biology of marine bottom communities. Bull. Bingham oceanogr. Coll. 15, 345-414.

- 1968. Marine benthic diversity: a comparative study. Am. Nat. 102, 243-282.

Schwarz, J. R., Yayanos, A. A. \& Colwell, R. R., 1976. Metabolic activities of the intestinal microflora of a deep-sea invertebrate. Appl. environm. Microbiology 31, 46-52.

Segerstrale, S. G., 1973. Results of bottom fauna sampling in certain localities in the Tvarminne area (inner Baltic), with special reference to the so-called Macoma-Pontoporeia theory. Commentat. biol. 67, 1-12.

Shugart, H. H., 1973. Succession: Similarities of species turnover rates. Science, N.Y. 180, 1379-1381.

Slabaugh, W. H. \&. Stump, A. D., 1964. Surface areas and porosity of sediments. J. geophys. Res. 69, 4773-4778.

Smith, K. L., 1971. A device for sampling immediately above the sediment-water interface. Limnol. Oceanogr. 16, 675-677.

Ward, A. R., 1975. Studies on the sublittoral free-living nematodes of Liverpool Bay. II. Influence of sediment composition on the distribution of marine nematodes. Mar. Biol. 30, 217-226.

Wildish, D. J., 1970. Some factors affecting the distribution of Orchestia Leach in estuaries. J. exp. mar. Biol. Ecol. 5, 276-284. 
- 1976. Determination of adenosine 5'-triphosphate in estuarine water and sediments by firefly bioluminescence assay. Tech. Rep. Fish. mar. Serv. Res. Dev, 649, 45 pp.

Wolff, W. J., 1974. Benthic diversity in the Rhine-Meuse estuary. Hydrobiol. Bull. 8, $242-252$.

Woodin, S. A., 1974. Polychaete abundance patterns in a marine soft-sediment environment: The importance of biological interactions. Ecol. Monogr. 44, 171-187.

Zobell, C. E., 1946. Marine microbiology. Chronica Botanica Co., Waltham, Mass. 240 pp.

Author's address: Dr. D. J. Wildish

Department of the Environment

Fisheries and Marine Service

Biological Station

St. Andrews, N.B. EOG $2 X O$

Canada 